\title{
EFFECTS OF BEE VENOM ON ACTIVITY AND EXPRESSION OF 15-LIPOXYGENASE-1 IN HUMAN HT29 COLON CANCER
}

\author{
MARYAM ZARE ${ }^{1}$, JINA KHAYATZADEH ${ }^{1}$, HAMIDREZA SADEGH NIA ${ }^{2}$, MAJID MOJARAD ${ }^{3}$, \\ FATEMEH BAGHBANI ${ }^{3}$, JAVAD SARGOLZAEI ${ }^{4}$, HAMID SADEGHIAN ${ }^{5}$ MOHSEN SISAKHTI $^{6}$ \\ and MOHAMMAD SOUKHTANLOO ${ }^{1,6 *}$
}

${ }^{1}$ Department of Biology, Faculty of Science, Islamic Azad University, Mashhad Branch, Mashhad, Iran

${ }^{2}$ Pharmacological Research Center of Medicinal Plants, School of Medicine,

Mashhad University of Medical Sciences, Iran

${ }^{3}$ Department of Human Genetic, Faculty of Medicine,

Mashhad University of Medical Science, Mashhad, Iran

${ }^{4}$ Department of Biology, Faculty of Science,

Arak University, Arak, Iran.

${ }^{5}$ Department of Laboratory Sciences, School of Paramedical Sciences,

Mashhad University of Medical Science, Mashhad, Iran

${ }^{6}$ Department of Medical Biochemistry, Faculty of Medicine,

Mashhad University of Medical Sciences, Mashhad, Iran

\begin{abstract}
Colorectal cancer has a high incidence rate with significant mortality and morbidity. The 15-lipoxygenase-1 (15-LOX-1) is a crucial enzyme as well as a tumor suppressor, especially in colon cancer. Bee venom, by the induction of apoptosis, is a promising new anti-cancer agent. Thus, the effects of bee venom on the expression of 15-LOX-1 m-RNA and its activities in the HT-29 cell line have been investigated in the current study. Human HT-29 colon cancer cells were treated with increasing concentrations of bee venom (1.87-30 $\mu \mathrm{g} / \mathrm{mL})$, and cisplatin $(5 \mu \mathrm{g} / \mathrm{mL})$ as the positive control for $24-$ and $48-\mathrm{h}$. Then, cell viability and apoptosis were measured using the MMT assay and flow cytometry, respectively. Enzyme activity and expression were assayed using the kinetic method and real-time PCR, respectively. The results showed that the main content of bee venom was with a retention time of $60 \mathrm{~min}$. The IC50 values of bee venom at 24- and 48-h were $6.01 \mu \mathrm{g} / \mathrm{mL}$ and $4.44 \mu \mathrm{g} / \mathrm{mL}$, respectively. Expression of 15-LOX-1 in cancer cells treated with bee venom increased (p $<$ $0.0005)$, as well as the activity of the enzyme in the presence of bee venom $(\mathrm{p}<0.01)$. The current study revealed the apoptotic and cytotoxic effects of bee venom against the human colon cancer HT-29 cell line that was not seen in fibroblast cells. Findings suggest that bee venom may have therapeutic effects against the HT29 colon cancer cell through the induction of the15-LOX-1 pathway. However, further studies are needed in this regard.
\end{abstract}

Keywords: Bee venom, Apoptosis, Colorectal Cancer, 15-lipoxygenase-1, High-Performance Liquid Chromatography (HPLC)

Colorectal cancer (CRC) is known to be the third leading cause of cancer death in both men and women throughout the world (1). In developed countries, CRC is the third most common malignancy. Unfortunately, routine colon cancer therapies such as surgery, radiation-based therapy, chemotherapy, and targeted therapy are not able to cure this disease. However, the discovery of new interven- tions for the treatment of colon cancer with low side effects are ongoing (2). Bio-toxins, which are produced by many insects as a defense against predators, are known to have both pharmacological as well as toxicological effects $(3,4,5)$. Apitoxin, also known as bee venom (BV), is a natural product that has been used for treating rheumatoid arthritis, multiple sclerosis, and many other diseases $(6,7)$. Bee

$\bar{*}$ Corresponding author: e-mail: soukhtanloom@mums.ac.ir 
venom comprises several biologically active peptides that include Melittin as its main content, enzymes, and bioactive amines components with different properties (8).

Studies have shown that bee venom is known to have radio-protective, anti-mutagenic, antiinflammatory, antinociceptive, and anti-cancer properties (9). Accumulating evidence suggests bee venom has an effect on cell proliferation and the induction of apoptosis and necrosis that does not encourage the growth of other types of cancer cells (10). It is important to note that bee venom is able to exert anti-tumor function through increasing the expressions of apoptotic proteins such as P53, Bax, Caspases 8, 3, 7, and decreasing the expressions of anti-apoptotic protein B-cell lymphoma 2 (Bcl-2) and $\mathrm{Bcl}-\mathrm{Xl}(10,11)$.

The anti-cancer activities of bee venom led to numerical investigation into its natural toxin properties (12). Zheng et al. have suggested that bee venom could inhibit colon cancer cell growth by the induction of apoptosis through activation of (the Death Receptor) DR4 and DR5 and inhibition of $\mathrm{NF}-\kappa \mathrm{B}$ in colon cancer cells (13). Another research has suggested that bee venom inhibits cervical tumor growth through the enhancement of FAS, DR3, and DR6 expression via the inhibition of the NF- $\kappa \mathrm{B}$ pathway (14).

In vitro and in vivo studies have shown that the anti-tumor effect of bee venom in prostate cancer cells induces apoptosis by NF- $\mathrm{\kappa B} /$ Caspase (15). Among the many molecular changes in the adenoma and the metastasis of colon cancer, one of these changes is the loss of 15-LOX-1 expression in colon cancer $(16,17)$. In contradiction with these studies, immunohistochemical staining studies on colorectal cancer and blotting techniques have confirmed that 15-LOX-1 is overexpressed in this tissue (18). Furthermore, 15-LOX-1 enzyme expression is specially regulated and has an important role in cancer cells, especially in colorectal cancer cells (19). Many studies have also shown that $15-\mathrm{LOX}-1$ acts as a tumor suppressor, and expression of the 15LOX-1 decreases in colon cancer (20).

The products of the enzyme have various antiinflammatory activities and it is able to induce the differentiation of colon cancer cells (21). Because of the importance of 15 -LOX-1 in colon cancer, we have compared the cytotoxic and apoptotic effects of honeybee venom on human colon cancer HT-29 and murine normal fibroblast L929 cell lines. Following treatment of bee venom on the cancer cells, the expression level of 15-LOX-1 gene and its activities were investigated.

\section{EXPERIMENTALS}

The lyophilized powder of bee venom (Apis mellifera) was obtained from Royan Zahr (Isfahan, Iran. The 3-(4, 5-dimethylthiazol-2yl)-2, 5 diphenyltetrazolium bromide (MTT) and propidium iodide (PI) were purchased from Sigma-Aldrich (St. Louis, MO, USA). Roswell Park Memorial Institute medium (RPMI-1640), fetal bovine serum (FBS), and a penicillin-streptomycin solution were prepared from Gibco (Life Technologies, Carlsbad, CA, USA). The cDNA syntheses kit was purchased from Pars Toos Co (Mashhad, Iran) and the RT-PCR kit was obtained from Solis Bio-Dyne (Estonia). Human colon cancer HT29 and murine normal fibroblast L929 cell lines were obtained from Pasteur Institute (Tehran, Iran).

\section{HPLC analysis of bee venom}

Natural bee venom was prepared from the persica species worker honeybees, which were purchased from the Royan Zahr Company, Isfahan, Iran. Bees were native to the Chahar Mahal and Bakhtiari Mountain region, Kouhrang, Iran. Bee venom was collected by electrically shocking the bees and after extraction, the bee venom was dried, packaged, and storage at $-4^{\circ} \mathrm{C}$ and kept away from sunlight.

The HPLC experiment was carried out using the KNAUER HPLC system (Berlin, Germany) equipped with a K-1001 pump and a UV detector that was set at $214 \mathrm{~nm}$. Chromatographic separation was performed on a C18 column (Knauer Eurosfer100) using the gradient elution with $0.1 \%$ trifluoroacetic acid (TFA) in distilled water and acetonitrile with some modifications (22).

\section{Cell culture and proliferation assay}

The human colon cancer HT-29 and normal fibroblast L929 cell lines were cultured in RPMI1640 medium, containing FBS $(10 \%)$ and $1 \%$ penicillin-streptomycin solution $(10,000 \mathrm{U} / \mathrm{mL}$ penicillin and $10 \mathrm{mg} / \mathrm{mL}$ streptomycin) that was kept in a fully humidified environment at $37^{\circ} \mathrm{C}$ with $5 \% \mathrm{CO}_{2}$. The culture medium was replaced thrice a week.

The cells were seeded $\left(1 \times 10^{4}\right.$ cells/well $)$ in 96-well plates. After $24 \mathrm{~h}$ and the confluent of cells in the well, the upper medium was replaced with the culture medium containing different concentrations of bee venom $(30,15,7.5,3.75,1.875 \mu \mathrm{g} / \mathrm{mL})$, cisplatin $(5 \mu \mathrm{g} / \mathrm{mL})$ as the positive control, and the vehicle Phosphate Buffer Saline (PBS) as the negative control (23). After 24- and 48-h of incubation, the viability of the HT-29 and L929 cells was deter- 
mined using the MTT assay. Briefly, $10 \mu \mathrm{L}$ of MTT reagent $(5 \mathrm{mg} / \mathrm{mL}$ in PBS) was added to each well, and the plates were further incubated for $4 \mathrm{~h}$ at $37^{\circ} \mathrm{C}$. At the end of incubation time, the media was removed, and formazan crystals were dissolved by adding $150 \mu \mathrm{L}$ dimethyl sulfoxide. Finally, the absorbance monitored at $545 \mathrm{~nm}$ and $630 \mathrm{~nm}$ using Stat Fax 2100 microplate reader. The assay was carried out in triplicate.

\section{Apoptosis assay}

The HT29 cells were cultured $\left(1 \times 10^{5}\right.$ cells per well) in 6-well plates for $24 \mathrm{~h}$. Confluent cells were treated with honeybee venom $(0,30,7.5 \mu \mathrm{g} / \mathrm{mL})$ and $5 \mu \mathrm{g} / \mathrm{mL}$ of cisplatin. After $48 \mathrm{~h}$ of incubation, the floating and adherent cells were harvested and the cells were washed with PBS and resuspended in $750 \mu \mathrm{L}$ of a hypotonic buffer $(50 \mu \mathrm{g} / \mathrm{mL}$ PI in $0.1 \%$ sodium citrate and $0.1 \%$ Triton $\mathrm{X}-100$ ) at $4{ }^{\circ} \mathrm{C}$ overnight in the dark before flow cytometric analysis. The samples were then analyzed with BD FACSC in the flow cytometer (BD Biosciences, San Jose, CA, USA). For each sample, 10,000 events were recorded and the data were analyzed using Win MDI (version 2.8) software. Three independent experiments were performed.

\section{Quantification of 15-LOX-1 with real time-PCR}

The mRNA expression level of 15-LOX-1 was determined by the real-time PCR analysis technique. In brief, approximately $1 \times 10^{6}$ cells were homogenized with tripure isolation reagent (Roche) and the total RNA was isolated according to the manufacturer's protocol (24). The cDNA was synthesized by Pars Toos kit according to the manufacturer's instruction. Based on the sequence of human 15 LOX-1, primers 5'-ACCAGGTTTGCCACTTTGTC-3' (forward) and 5'-CAGTGTCGCCATCACTGTCT-3' (reverse) were designed. PCR amplification was carried out in a reaction volume of $20 \mu \mathrm{L}$ containing $1 \mu \mathrm{L}$ of cDNA and $1 \mu \mathrm{L}$ of primer $(10 \mathrm{pM}) 2 \mu \mathrm{L}$ of $10 \mathrm{X}$ buffer, $1.4 \mu \mathrm{L}$ of $2.5 \mathrm{mM} \mathrm{MgCl}_{2}, 1.2 \mu \mathrm{L}$ of $\mathrm{dNTP}, 0.3 \mu \mathrm{L}$ of Taq DNA polymerase, and $13.1 \mu \mathrm{L}$ of DEPCI water. The PCR was performed using the Bio-Rad system (Hercules, CA) under the following conditions: Initial denaturation at $95^{\circ} \mathrm{C}$ for $5 \mathrm{~min}, 40$ amplification cycles, that each consisted of denaturation at $95^{\circ} \mathrm{C}$ for $30 \mathrm{~s}$, annealing at $58^{\circ} \mathrm{C}$ for $30 \mathrm{~s}$, an extension at $72^{\circ} \mathrm{C}$ for $30 \mathrm{~s}$, and an additional extension step at $72^{\circ} \mathrm{C}$ for $5 \mathrm{~min}$. The conditions were similar regarding the GAPDH (glyceraldehyde-3-phosphate dehydrogenase) as the housekeeping gene. Quantitative real-time PCR was carried out on the Applied Biosystems Step One plus instrument, utilizing the SYBR Green PCR Master Mix. The amplification reactions were performed under the following conditions: $20 \mathrm{~s}$ at $95^{\circ} \mathrm{C}, 40$ cycles of $65^{\circ} \mathrm{C}$ for $30 \mathrm{~s}$, and $72^{\circ} \mathrm{C}$ for $45 \mathrm{~s}$. A final period of $72^{\circ} \mathrm{C}$ for $5 \mathrm{~min}$ was considered to ensure maximum production. Samples were normalized to GAPDH. The cycle threshold (CT) for each run was set as 0.1 when amplification was observed in the log phase. Relative gene expression was determined by using the $\Delta \Delta^{\mathrm{CT}}$ method (25).

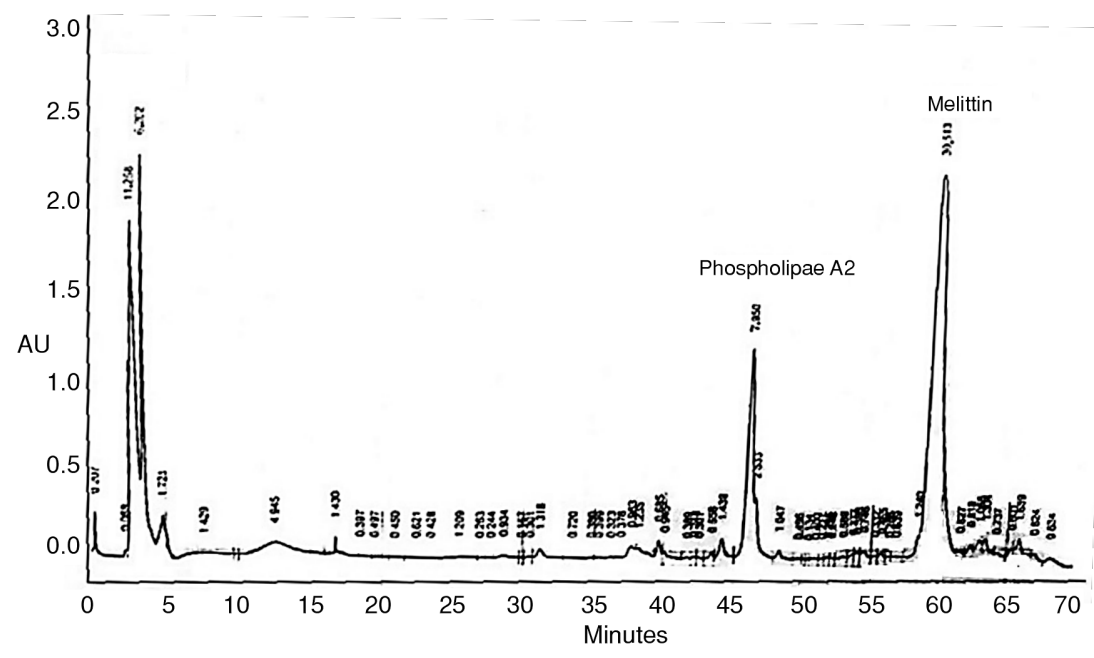

Figure 1. Chromatogram of bee venom in HPLC analysis

The fractions showed that bee venom contains two main compounds, mellitin (30.5\%) and phospholipase A2 (8\%). The retention time of melittin and phospholipase A2 was 60 and 47 min respectively. 


\section{Measurement of 15-LOX-1 activity in the pres- ence of bee venom}

Enzyme activity of 15-LOX-1 was measured according to the method of Malterud et al. (26). Briefly, $1 \times 10^{6}$ HT29 colon cancer cells were incubated with $7.5 \mu \mathrm{g} / \mathrm{mL}$ of bee venom for $48 \mathrm{~h}$, and then the cells were scraped and homogenized using a sonicator (Sonopuls mini 20 Germany) at $20 \mathrm{~Hz}$ for one minute. The homogenate incubated in borate buffer $(0.1 \mathrm{M}, \mathrm{pH}=9)$ and linoleic acid (final concentration $134 \mu \mathrm{M})$ as substrate at $20^{\circ} \mathrm{C}$. The absorbance at 234 $\mathrm{nm}$ for $60 \mathrm{~s}$ was measured by the spectrophotometer and activity expressed as (\% of control).

\section{Statistical analysis}

Data were expressed as Mean $\pm \mathrm{SEM}$. The test was performed using a one-way ANOVA, followed by the Bonferroni test for several comparisons. A probability level of $p<0.05$ was considered statistically significant.

\section{RESULTS}

\section{Main components of bee venom in HPLC}

Based on the results of chromatography, over a hundred very small and large peaks were obtained with column $\mathrm{C} 18$ and several main peaks could be detected in the main chromatogram. The retention time of melittin and phospholipase $\mathrm{A}_{2}$ was determined to be 60 and 47 min respectively (Fig. 1). The area under the curve of melittin and phospholipase $\mathrm{A}_{2}$ fraction was about 30.513 and $7.850 \%$ of the total composition of honeybee venom, respectively. That is consistent with previous reports on the amount of melittin in honeybee venom; however, the amount of melittin fraction was low.

\section{Effects of bee venom on the viability of HT 29 colon cancer cells}

The results indicated that bee venom is able to reduce the proliferation of the HT-29 cell line in a concentration- and time-dependent manner. The fifty percent inhibitory concentrations $\left(\mathrm{IC}_{50}\right)$ of bee venom were found to be 6.01 and $4.44 \mu \mathrm{g} / \mathrm{mL}$ at $24-$ and 48-h, respectively, which are comparable with cisplatin (Figs. 2 A, B). Bee venom did not exhibit significant cytotoxicity toward normal L929 fibroblast cells as shown in Figure $2 \mathrm{C}$.

\section{Effect of bee venom on the apoptosis of cancer} cells

As illustrated in Figure 3, bee venom significantly and dose-dependently increased apoptotic

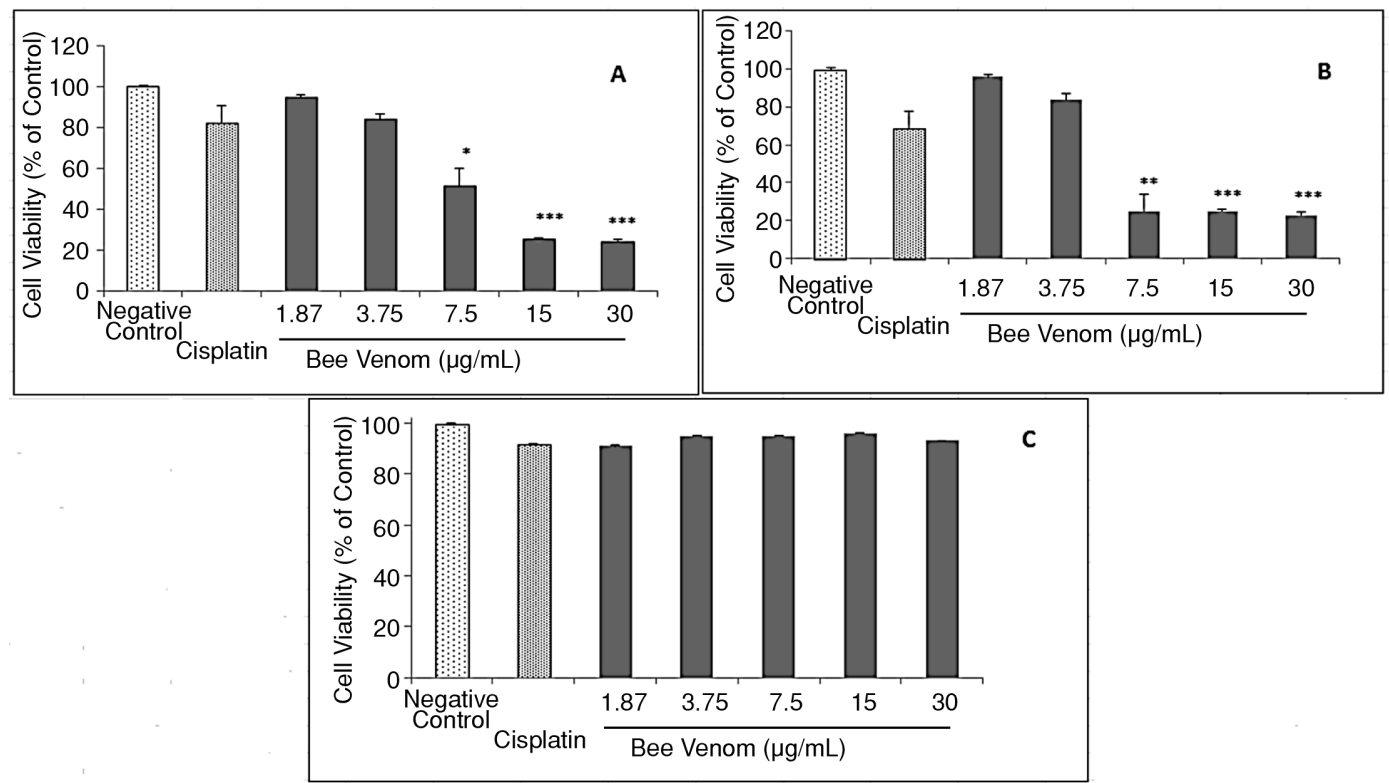

Figure 2. The effects of bee venom on cell proliferation and viability of human HT29 colon cancer cells and fibroblast cells. The cells were treated $24 \mathrm{~h}$ (A) and $48 \mathrm{~h}$ (B) with different concentrations of bee venom $(1-30 \mu \mathrm{g} / \mathrm{mL})$ and cisplatin $(5 \mu \mathrm{g} / \mathrm{mL})$ as the reference drug. For murine L929 fibroblast cells (normal cell), no significant difference was seen after $48 \mathrm{~h}$ between the treatment and control group $(\mathrm{C}) .{ }^{*} \mathrm{p}<0.05$ versus control cells; ${ }^{* *} \mathrm{p}<0.01$ versus control cells; *** $\mathrm{p}<0.001$ versus control cells. Data are shown as Mean \pm SEM. 


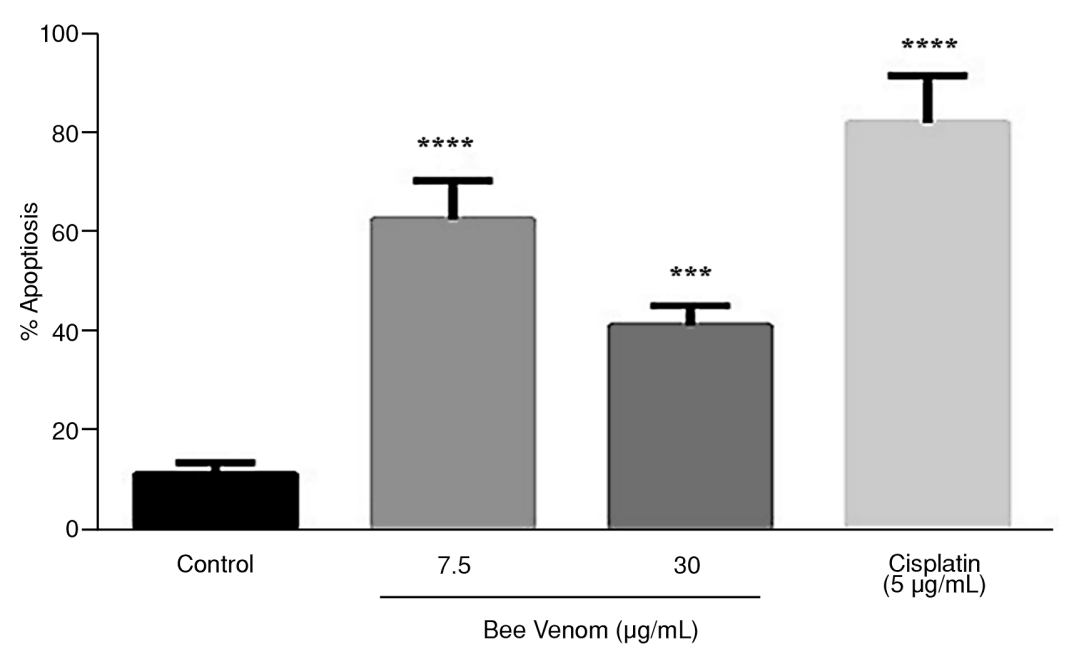

Figure 3. The effect of bee venom on the apoptosis of human HT29 colon cancer cells

The cancer cells were treated with different concentrations of bee venom $(0,7.5,30 \mu \mathrm{g} / \mathrm{mL})$ and cisplatin $(5 \mu \mathrm{g} / \mathrm{mL})$ for $48 \mathrm{~h}$. Percentage of apoptosis in the treatment group significantly increased in comparison to the control group; $* * * \mathrm{p}<0.001 \mathrm{versus} \mathrm{control} \mathrm{cells}(0 \mu \mathrm{g} / \mathrm{mL}$ of bee venom); $* * * * p<0.0005$ versus control cells. Data are shown as Mean \pm SEM

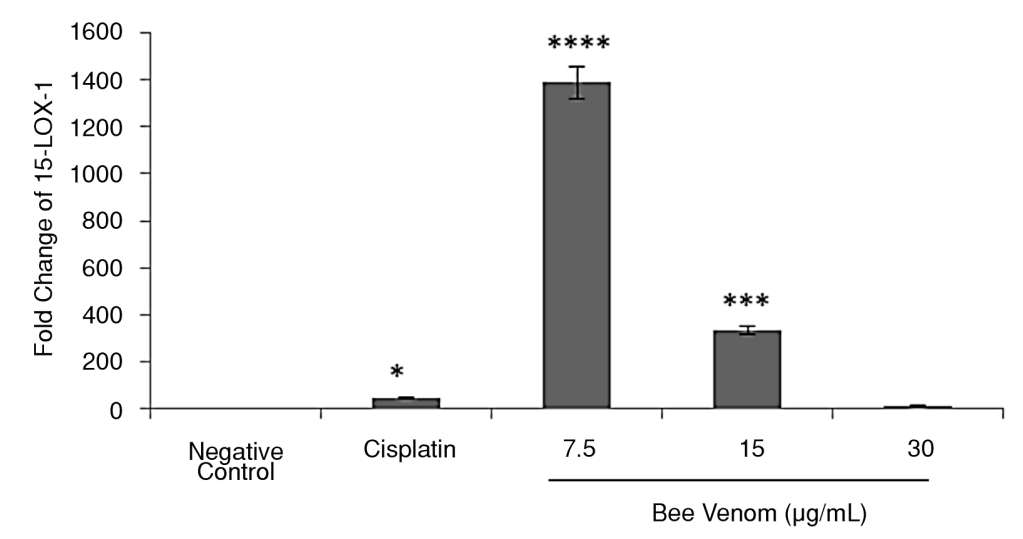

Figure 4. The effect of bee venom on 15-LOX-1 gene expression in the HT-29 colon cancer cell

The mRNA level of 15-LOX-1 was measured in untreated cells or the control group ( $0 \mu \mathrm{g} / \mathrm{mL}$ of bee venom) and those exposed to bee venom $(7.5,15,30 \mu \mathrm{g} / \mathrm{mL})$ and cisplatin $(5 \mu \mathrm{g} / \mathrm{mL}$ as positive controls $)$ for $24 \mathrm{~h}$. Bee venom $(7.5 \mu \mathrm{g} / \mathrm{mL})$ in comparison to the negative (without bee venom) and positive controls (cisplatin) very significantly increased expression $15-\mathrm{LOX}-1 \mathrm{mRNA} .{ }^{*} \mathrm{p}<0.05 ; * * * \mathrm{p}<0.001$; $* * * * \mathrm{p}<0.0005)$. GAPDH gene, a housekeeping gene, was used as the internal control. Data are shown as Mean \pm SEM

cell death upon 48-hour incubation. The effect was comparable with the standard anti-neoplastic cisplatin. Percentage of apoptosis in the treatment group ( 7.5 and $30 \mu \mathrm{g} / \mathrm{mL}$ of bee venom) significantly increased $(\mathrm{p}<0.0005$ and $\mathrm{p}<0.001)$ versus the control cells $(0 \mu \mathrm{g} / \mathrm{mL})$, respectively.

\section{Effects of bee venom on expression and activity of} 15-LOX-1 in HT29 Cells

Treatment with bee venom can lead to 332-fold up-regulation of 15-LOX-1 mRNA expression levels at $24 \mathrm{~h}$ (compared with untreated control cells).
As Figure 4 shows, the maximum level of 15-LOX$1 \mathrm{mRNA}$ expression is related to the concentration of $7.5 \mu \mathrm{g} / \mu \mathrm{L}$, which can affect more significantly than the control $(\mathrm{p}<0.0005$ and $\mathrm{p}<0.001)$.

As shown in Figure 5, bee venom $(7.5 \mu \mathrm{g} / \mu \mathrm{L})$ significantly promoted the activity of $15-\mathrm{LOX}-1$ in HT-29 cancer cells about three times more than the control (without bee venom) $(p<0.01)$. The result of the activity was almost similar to the expression level of the enzyme, which was approximately a 3-fold increase in the activity of the enzyme in return to a 300 -fold in the mRNA expression of 15-LOX-1. 


\section{DISCUSSION}

Bee venom inhibited the growth of HT-29 colon cancer cells by up-regulating the expression of the 15-LOX-1 enzyme and the induction of apoptosis, which is dependent on the melittin content of bee venom.

Similar to other studies, melittin was the last fraction that was eluted from the column after apamin and phospholipase $A_{2}$ (22). Our result has shown the retention time of melittin was determined at $60 \mathrm{~min}$ according to the chromatogram (Fig. 1). In the same study, the area under the curve of the melittin fraction was about $50 \%(49.85 \%)$ and its retention time was $42 \mathrm{~min}$ (27). In another research, the melittin of bee venom was separated by a gradient of $5-52 \%$ acetonitrile in reverse-phase high-performance liquid chromatography with a retention time less than $15 \mathrm{~min}$ (28). Because of the impurity of our bee venom and different working methods in the HPLC analysis, in comparison to other studies, the retention time of our bee venom was high.

We found that honeybee venom has potent cytotoxic effects on colon cancer cells similar to other studies (13). The results showed that the dosedependent manner of bee venom decreased the growth of HT-29 cells by inducing apoptosis. Our result was identical to another study where a similarity in $\mathrm{IC}_{50}$ of bee venom was observed. In Amini et al.'s study, the $\mathrm{IC}_{50}$ was $6 \mu \mathrm{g} / \mathrm{mL}$ (29). Based on the results of Jang M-H et al., the concentration of bee venom-induced cytotoxicity was set at around $10 \mu \mathrm{g} / \mathrm{mL}(30)$.
Our results (Figs. 2 A, B, C) were similar to previous studies that demonstrated bee venom dosedependently increased the apoptosis rate and did not exert any cytotoxic effects on the normal cells (15, 31,32 ).

It is understood that some pathways in cancerous cells are more active than normal cells. The role of 15-LOX-1 enzyme and its products in colon cancer were thoroughly studied (19). It has been shown that the higher expression level of 15-LOX-1 inhibited cell invasion $(19,33)$, suppressed metastasis (19, 34 ), and increased terminal differentiation and apoptosis in cancerous cells $(16,19)$. Although, our result showed that apoptosis increased in the HT-29 colon cancer cell line, further investigation on the effect of bee venom in the invasion of these cells is needed.

Many different studies have shown that bee venom reduces the cell proliferation of cancerous cell culture and animal model. In addition, Lee et al. suggested that bee venom inhibits cervical tumor growth through the enhancement of FAS, DR3, and DR6 expression via the inhibition of the NF- $\kappa$ B pathway (14). In another study, it has been proven that death receptor expression and the JAK2/STAT3 pathway was inhibited in human ovarian cancer cells by bee venom and melittin (31). In vitro and in vivo, anti-tumor effects of bee venom in prostate cancer cells were studied and it has been shown that bee venom induces apoptosis by NF- $\mathrm{KB} /$ caspase (15).

On the other hand, bee venom exerts an anticancer effect on human lung cancer cells via inhibition of mRNA expression of cyclooxygenase-2 (COX-2) and synthesis of prostaglandin E (30).

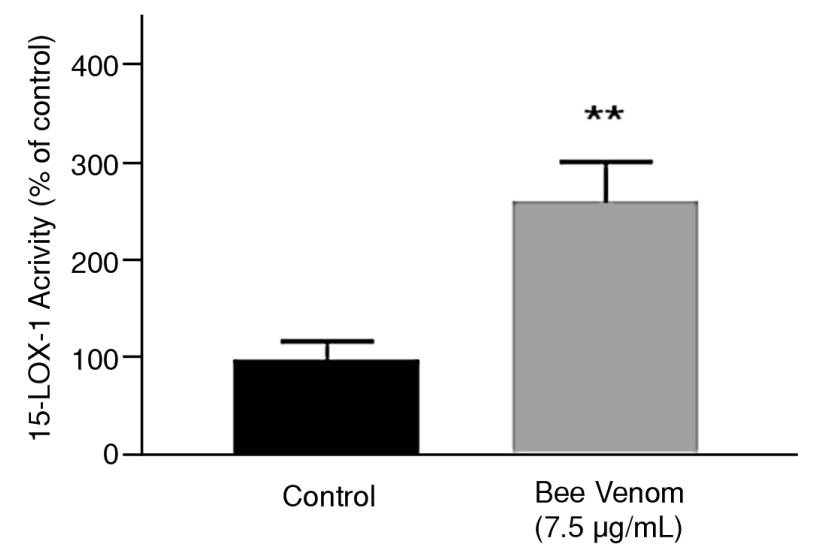

Figure 5. The effects of bee venom on 15-LOX-1 activity in the HT-29 cancer cells.

Bee venom $(7.5 \mu \mathrm{g} / \mathrm{mL})$ after $48 \mathrm{~h}$ of treatment significantly promoted the activity of 15 -LOX-1 compared to (\% of control) the control group $(* * \mathrm{p}<0.01)$. The activity of 15 -LOX-1 increased approximately 3 -times more than the control. Data are shown as Mean \pm SEM. 
Similarly, celecoxib, a selective COX2 inhibitor, increased apoptosis by overexpression of 15-LOX-1 mRNA in colon cancer cells (17). No studies have been done on the effects of bee venom against 15LOX-1 in colon cancer. According to our data, for the first time, bee venom like celecoxib increased apoptosis via overexpression of 15-LOX-1 mRNA. Many evidence has shown that expression of 15LOX-1 decreased in colon cancer; hence, inducing the expression of $15-\mathrm{LOX}-1$ could be used in the treatment of colon cancer (18).

The cytotoxic effects of honeybee venom and bioactive peptides (e.g., melittin and phospholipase A2) on different cancerous cells including kidney, ovarian, lung, prostate, and bladder cancers were previously reported $(15,30,31,35)$.

Methylation of DNA promoter contributes to transcriptional silencing of various tumor-suppressor genes in cancer cells (36). Another hypothesis is that DNA methylation of the promoter 15-LOX-1 is regulated by methylation of $\mathrm{CpG}$ sites, and possibly bee venom contributed to this regulation. Most likely, the other studies on bee venom that reported melittin has similar effects, most probably arise from melittin of bee venom (31).

Our results have shown the lack of consistency in the activity and gene expression of 15-LOX-1. The expression of the gene was very high in comparison to enzyme activity. Studies in this regard are contradictory, in terms of the type of cancer and enzyme. Such that, Wieczorek et al. reported that the gene expression and activity of the antioxidant enzymes were elevated in the blood of patients with bladder cancer (37). Takumi et al. showed that there was no correlation between mRNA expression levels and Orotate phosphoribosyl transferase (OPRT) activity in colorectal cancer $(\mathrm{r}=-0.4301, \mathrm{p}=$ 0.8926) (38). Similarly, it has been shown that bee venom up-regulated both of them, the expression and the activity of the enzyme, although the fold of expression was very high (Figs. 4, 5).

\section{CONCLUSION}

The current evidence suggests that bee venom inhibits the growth of HT-29 colon cancer cells by up-regulating the expression of the 15-LOX-1 enzyme and inducing apoptosis. Further studies are needed to identify the pathway involved mechanistically in the up-regulation of 15-LOX-1 expression. Because of the importance of 15-LOX-1 in colon cancer, agents that regulate the 15 -LOX-1 expression like bee venom plays a critical role as effective drugs for treatment or inhibition of colon cancer.

\section{Acknowledgments}

Authors would like to thank the Mashhad University of Medical Sciences and The Islamic Azad University of Mashhad, Mashhad Branch for their financial support.

\section{REFERENCES}

1. Siegel R. L., Miller K.D., Jemal A.: CA Cancer J. Clin. 66, 7 (2016).

2. Qureshi A., Verma A., Ross P., Landau D.: BMJ Clin. Evid. 2010 (2010).

3. Liu X., Chen D., Xie L., Zhang R.: J. Pharm. Pharmacol. 54, 1083 (2002).

4. Moon D.O., Park S.Y., Heo M.S., Kim K.C., Park C. et al.: Int. Immunopharmacol. 6, 1796 (2006).

5. Zhang Y.: Zool. Res. 36, 183 (2015).

6. Kwon Y.B., Lee J.D., Lee H.J., Han H.J., Mar W.C. et al.: Pain 90, 271 (2001).

7. Park H.J., Lee S.H., Son D.J., Oh K.W., Kim K.H. et al.: Arthritis Rheum. 50, 3504 (2004).

8. Heinen T.E., da Veiga A.B.: Toxicon 57, 497 (2011).

9. Hossen M.S., Shapla U.M., Gan S.H., Khalil M.I.: Molecules 22, 25 (2016).

10. Orsolic N.: Cancer Metast. Rev. 31, 173 (2012).

11. Alizadehnohi M., Nabiuni M., Nazari Z., Safaeinejad Z., Irian S.: J. Venom. Res. 3, 22 (2012).

12. Rady I., Siddiqui I.A., Rady M., Mukhtar H.: Cancer Lett. 402, 16 (2017).

13. Zheng J., Lee H.L., Ham Y.W., Song H.S., Song M.J. et al.: Oncotarget 6, 44437 (2015).

14. Lee H.L., Park S.H., Kim T.M., Jung Y.Y., Park M.H. et al.: Oncotarget 6, 7280 (2015).

15. Park M.H., Choi M.S., Kwak D.H., Oh K.W., Yoon D.Y. et al.: Prostate 71, 801 (2011).

16. Shureiqi I., Wu Y., Chen D., Yang X.L., Guan B. et al.: Cancer Res. 65, 11486 (2005).

17. Heslin M.J., Hawkins A., Boedefeld W., Arnoletti J.P., Frolov A. et al.: Ann. Surg. 241, 941 (2005).

18. Ikawa H., Kamitani H., Calvo B.F., Foley J.F., Eling T.E.: Cancer Res. 59, 360 (1999).

19. Lee S. I., Zuo X., Shureiqi I.: Cancer Metast. Rev. 30, 481 (2011).

20. Shureiqi I., Wojno K.J., Poore J.A., Reddy R.G., Moussalli M.J. et al.: Carcinogenesis 20, 1985 (1999).

21. Moussalli M.J., Wu Y., Zuo X., Yang X.L., Wistuba I.I. et al.: Cancer Prev. Res. (Phila) 4, 1961 (2011). 
22. Rybak-Chmielewska H., Szczęsna T.: J. Apicultural Sci. 48, 103 (2004).

23. Lacour S., Hammann A., Grazide S., LagadicGossmann D., Athias A. et al.: Cancer Res. 64, 3593 (2004).

24. Sisakht M., Mashkani B., Bazi A., Ostadi H., Zare M. et al.: Rev. Bras. Farmacogn. 27, 324 (2017).

25. Livak K. J., Schmittgen T.D.: Methods 25, 402 (2001).

26. Malterud K.E., Rydland K.M.: J. Agric. Food Chem. 48, 5576 (2000).

27. Mahmoodzadeh A., Morady A., Zarrinnahad H., Ghasemi-Dehkordi P., Mahdavi M. et al.: Tehran University of Medical Sciences, 70 (2013).

28. Haghi G., Hatami A., Mehran M.: J. Apic. Sci. 57, 37 (2013).

29. Amini E., Baharara J., Nikdel N., Salek Abdollahi F.: Asia Pac. J. Med. Toxicol. 4, 68 (2015).
30. Jang M.H., Shin M.C., Lim S., Han S.M., Park H.J. et al.: J. Pharmacol. Sci. 91, 95 (2003).

31. Jo M., Park M.H., Kollipara P.S., An B.J., Song H.S. et al.: Toxicol. Appl. Pharm. 258, 72 (2012).

32. Choi K.E., Hwang C.J., Gu S.M., Park M.H., Kim J.H. et al.: Toxins (Basel) 6, 2210 (2014).

33. Cimen I., Tuncay S., Banerjee S.: Cancer Sci. 100, 2283 (2009).

34. Wu Y., Mao F., Zuo X., Moussalli M.J., Elias E. et al.: Cancer Med. 3, 472 (2014).

35. Ip S. W., Chu Y.L., Yu C.S., Chen P.Y., Ho H.C. et al.: Int. J. Urol. 19, 61 (2012).

36. Zuo X., Shen L., Issa J.P., Moy O., Morris J.S. et al.: FASEB J, 22, 1981 (2008).

37. Wieczorek E., Jablonowski Z., Tomasik B., Gromadzinska J., Jablonska E. et al.: Anticancer Res. 37, 841 (2017).

38. Takumi O., Michiharu S., Kazuhiko N., Hajime N., Tsuyoshi O. et al.: Gan To Kagaku Ryoho 29, 2515 (2002).

Received: 31.12.2017 